\title{
Russell as a man of letters
}

In English literary parlance today a man of letters is a literary man other than the poet, dramatist and novelist, although it is still permissible to include in the class, in special cases, all writers in prose and verse. The well-known series of biographies called English Men of Letters put Shakespeare, David Hume and Richard Bentley in the same company. I mention Russell as a man of letters in the sense of a writer of literary prose, that is, in the sense in which Walter Scott used the expression more than 150 years ago, when he called a particular writer both a man of letters and a poet.

A consideration of Russell as a writer may be particularly important today if only to stress the vital link between philosophy and literature. "No man was ever yet a great poet, without being at the same time a profound philosopher", said Coleridge; but I am afraid our universities now dismiss this view as that of a poet who was also a philosopher of a sort even when they approve a subject like "The Influence of German Transcendental Philosophy on English Romantic Poetry" for a doctoral thesis in a literature department. Our academic pigeon-holes offer little scope for the integration of the liberal arts, although they alone can enlarge and deepen our understanding of life as a whole.

The idea of a disjunction between poetry and philosophy in this century begins with Croce's too rigid differentiation between the rational and the intuitive. Psychologically it is as untenable as Francis Bacon's tripartite division of the human mind into three faculties, memory, imagination and reason, producing history, poetry and philosophy, respectively. But the most fatal blow to the close relationship between poetry and philosophy came from I.A. Richards, who in his book science and Poetry (1925) denied poetry any philosophical value on the basis of a sharp distinction between the rational and the emotive. Several years Tater T.S. Eliot's remark that neither "Shakespeare nor Dante did any real thinking" became a prestigious critical dictum. Five years later F.R. Leavis declared that he would never consider Wordsworth a "philosophic thinker". Perhaps the only voice of common sense in this noisy dispute on philosophy in poetry is that of Susanne Langer. She, in her now critically influential work Feeling and Form (1953), does not call Wordsworth "the proponent of a bona fide philosophical theory" and yet finds in his "Ode on the Intimations of Immortality" a "piece of metaphysical reasoning".

But even when it is admitted that there is a kind of philosophy in poetry, the question remains - how much poetry can be there in philosophy? The answer is very largely determined by what we mean by philosophy. In the Middle Ages even alchemy was a branch of philosophy, and Chaucer knew 
one of its practitioners: "But all be that he was a philosopher, / Yet had he but little gold in his coffer." I was taught Aristotle by a Bengali professor in Calcutta who, after seven years of residence in oxford in the days of F.H. Bradley, was never tired of repeating that all human activity (perhaps including his not grading our exercises) was essentially a search for form and therefore philosophical. But all human activity is not equaliy poetical. Even a good deal of philosophical activity is sometimes not only unpoetical but disgustingly unliterary. As for myself I do not enjoy reading even those few paragraphs in Wittgenstein's later work which somehow I seem to understand.

Russell has a philosophy of metaphysics which brings it very close to mysticism and poetry. His best biographer, Alan Wood, calls him a "Passionate Sceptic". What is still more significant is that his unfinished book on Russe17's metaphysics begins with the sentence "Russell is a philosopher without a philosophy." Russell's book My Phizosophicat Development (1959) realiy is the story of a philosophical development, rather than that of the development of a philosophy. It was this undecisive, provisional nature of his successive metaphysical positions which prompted A.N. Whitehead to say that he was "a Platonic dialogue in himself". In "Reflections on My Eightieth Birthday", included in Russell's portraits from Memory (1956), he says: "I wanted certainty in the kind of way in which people want religious faith". The last paragraph of My Phizosophical Development is a lyrical confession that he is yet to find it.

When De Quincey made a sharp distinction between the literature of knowledge and the literature of power he did not reflect on those works of philosophical prose which can be at once literature of knowledge and of power. Russel1 was careful in stressing the elements in phitosophy which give it its power. In the last chapter of The Problems of Philosophy (1912) he speaks of the vatue of philosophy as an experience, as a personal testament. "In contemplation", he says here, "we start from the not-Self, and through its greatness the boundaries of Self are enlarged; through the infinity of the universe the mind which contemplates it achieves some share in infinity." He defines the end of philosophy almost in the language of a mystic: "through the greatness of the universe which philosophy contemplates, the mind also is rendered great, and becomes capable of that union with the universe which consitutes its highest good."

In 1914 Russell wrote the essay "Mysticism and Logic". It affirmed that "the greatest men who have been philosophers have felt the need both of science and of mysticism: the attempt to harmonize the two was what made their life, and what always must, for all its arduous uncertainty, make philosophy, to some minds, a greater thing than either science or religion." He found in Plato "the same twofold impulse... though the mystic impulse is distinctly the stronger of the two, and secures ultimate victory whenever the conflict is sharp." He was even attracted by what little he knew of oriental mysticism, as we can see from the remark: "Something of Hellenism, something, too, of oriental resignation, must be combined with its hurrying Western self-assertion before it can emerge from the ardour of youth into the mature wisdom of manhood." ("It" here refers to the philosophy of "progress".)

To my mind, a major misfortune of modern thought has been that Russe11 had no thorough acquaintance with Indian philosophy. Perhaps I do not say this as an Indian suffering from intellectual patriotism. I have often thought that Russell would have discovered in our philosophical literature something to move him, a metaphysic distilled from tears such as angels weep, a severe dialectic growing out of very tender roots of feeling such as, it seems to me, he desires all true philosophy to be. I possess a copy of the phizosophy of Pacifism (1915), a rare anti-war pamphlet by Russel1 which has as its motto one whole poem from Tagore's English Gitanjazi. After reading the book "with the very greatest interest", Russell wrote about it to Tagore in a letter now in the Tagore Archives. The letter reads in part:

[The poems] have some quality different from that of any English poetry - If I knew India perhaps I could find words to describe it, but as it is I can only say that I feel it has a value of its own, which English literature does not give. I wish I could read them in their original language.

I think Russell could not fully understand the Indian poet because he had no knowledge of the philosophical tradition of which Tagore was an inheritor and one of the most significant modern interpreters. In another letter, this one at McMaster, Russe11 describes his 1912 meeting with Tagore at Cambridge, saying that "his mystic air did not attract me". There was obviously a failure of communication between the Cambridge don with a flair for fluent conversation and the Bengali poet who expressed himself mostly through song and silence.

The inwardness which, he says, it is the business of philosophy to foster is the essence of oriental thought. Russell re-emphasizes this quality of philosophy in his History of Westem Prizosophy (1945). That it was written during the second world war gives it a quality of reflectiveness which we do not usualiy find in a book of this kind. In the introduction Russell calls philosophy the "No Man's Land" between science and theology. He values it more as a consolation in our uncertainty than as satisfactory answers to our questions: "To teach how to live without certainty, and yet without being paralyzed by hesitation, is perhaps the chief thing that philosophy, in our age, can still do for those who study it." Feeling, at once intense and deep, cannot be excluded from a phiiasophy conceived as a consolation. And Russell admits that feeling as a constituent of philosophy. In an essay called "A Philosophy for Our Time", 
included in Portraits from Memory, he says that "the value of philosophy is partly in relation to thought and partly in relation to feeling, though its effects in these two ways are closely interconnected." This idea of feeling as a factor in philosophical thought gives his metaphysic its ethical significance.

It is noteworthy that from amongst English poets he chooses for inclusion in the History Byron and not Shelley, the only poet on whom he ever wrote an entire essay. In this essay. "The Importance of Shelley", he says: "It was not only Shelley's despairs that I liked among his sentiments but also his apocalyptic hopes." In the third volume of the Autobiography he says he ance had a desire to "write an essay on 'Shelley the Tough' (as opposed to the 'ineffectual angel')." But the choice of Byron and not Shelley or Coleridge as the subject of a chapter in the History is significant for Russell's idea of philosophy, rather than of poetry. In a chapter on Shelley he could have dealt with the poet's debt to Plato and in a chapter on Coleridge he could have brought in the influence on him of German metaphysics. Russell selected Byron because he considered him more of an expression of the European temper of the Romantic period than any other poet. He was "more important as a myth than as he realiy was"; "his importance, especially on the continent, was enormous."

This stress on feeling as an important factor in the history of thought is only one aspect of Russell's ethical view of philosophy. Towards the end of his life this made him indifferent to philosophy itself. When David Pears wrote his Bertrand Fusselz and the British Tradition in Phitosophy (1967), he wished his manuscript to be seen by Russel1. He refused because, as Rupert Crawshay-Williams records in Russell Remembered (1970), "he did not want to concern himself any more with philosophy, since stopping the world from being blown up was more important." It was not renouncing philosophy: it was doing what his philosophy had taught him to do.

Russell did not write anything particularly significant on the relationship between philosophy and literature. Perhaps this was because he severely distinguished between different functions of language. He did this in a 1927 article entit]ed "Is Literature a Dead Art?":

Writing serves two different purposes, which were at one time combined but have gradually become more and more separated. On the one hanc it is a means of giving information; on the other hand it is one of the fine arts. One ought perhaps to add a third purpose, more lmportant rousing

But what was his estimation of the literary abilities of philosophers? From what he says about such abilities of some philosophers it appears he cared a good deal about style in their work. He calls Plato "an imaginative writer of great genius and charm". He says that Descartes had "an extraordinarily excellent style" ard adds that "it is very fortunate for modern philosophy that the pioneer had such an admirable literary sense." About George Berkeley he says that "he is a very attractive writer, with a charming style." He mentions David Hume's "Tove of literary fame" but is silent about the quality of his English. Rousseau was a little too rhetorical, but Russell does not forget to mention that Kant had to read his works several times "because, at first reading, the beauty of style prevented him from noticing the matter." His appreciation of Bergson's style is implicitly an unfavourable criticism of his philosophy which he thinks is "an imaginative and poetic view of the world", apart from his doctrines of space and time. Incidentally, both Bergson and Russell won the Nobel Prize in Literature.

But when you connect his remarks on style in philosophical prose with his views on the place of feeling and experience in philosophy, you have a fairly clear idea of his interest in the literary side of a metaphysician's work. The last sentence of the History of Westerm Philosophy gives the philosopher almost the role of a poet: "In abandoning a part of its dogmatic pretensions, philosophy does not cease to suggest and inspire a way of life." The connection I point to may seem novel, but I believe that it is supported in what follows.

The idea of philosophy as a source of inspiration gave Russell his care for style - the means through which the inspiration is to be transmitted to the reader. Thus his view of style, though hardly original, is important for a student of his prose. He not anly pursued a style of his own; he had a strikingly sensitive response to style in others. He records in his Autobiography a conversation with Lytton Strachey about what literature should aim at. The distinguished biographer replied "Passion". While Russell valued passion as a creative element in literature he did not make Lytton Strachey his madel in the art of prose. "His style is unduly rhetorical", he says, "and sometimes, in malicious moments, I have thought it not unlike Macaulay's. He is indifferent to historical truth and will always touch up the picture to make the lights and shades more glaring and the folly of famous people more obvious."

Russell had a very special admiration for the style of Walter Pater. His brother-in-law, Logan Pearsall Smith, was also an early influence, who stressed imitation. But as Russell himself wrote adequately on this aspect of his style, I will not repeat the details. Suffice it to say that he did not long try to imitate the styles of other writers. The period of imitation seems to end with "A Free Man's Worship". On the broad quesion of influence as a factor in forming one's own style, Russell said: "Although direct imitation is always to be deprecated, there is much to be gained by familiarity with good prose, especially in cultivating a sense of prose rhythm."

What Russell does not say in his observations on style may be more 
significant than what he does say. He values simplicity and economy of expression, and he values rhythm. But he does not see the relationship between these virtues. What is simple can also be rhythmic, but not necessarily. Lord Attlee's simple English was once parodied in a sentence 1ike this: "China is a big country where lots of Chinese live." Attlee certainly wrote better English, but it is possible to achieve only dullness by pursuing simplicty. Russeli had a special reason for stressing simplicity as the chief virtue of style. First, his concern with style was influenced by the demands of philosophical prose. As late as 1948 he remarked in Human Knowledge that "the philosopher must pursue truth even at the expense of beauty." And this prescription was the result of the view of language and style set out in the same work. "Language, in its beginnings," he says, "is pedestrian and practical, using rough and ready approximations which have at first no beauty and only a very limited degree of truth. Subsequent refinements have too often had aesthetic rather than scientific motives, but from the enquiry upon which we are about to embark aesthetic motives must, however reluctantly, be relentlessiy banished." Russell's theory of language does not necessarily lead to a theory of style. He admits emotion into philosophy. He considers style as rhythm. He believes that rhythm is an expression of personality. But nowhere in his writings is there a theory of style comprehending philosophical prose. He achieved style in spite of his convictions.

Secondly, Russell was very critical of professorial prose. He considered it a negation of the principle of simplicity. He thought academic style was becoming a kind of respectable verbiage, with long complicated sentences having greater weight in the world of learning than short and simple ones. In "How I write" he gives an imaginary example of a learned sentence such as a sociologist might write, which he then translates into English. He adds that "any professor who used the second sentence instead of the first would get the sack."

What is Russell's own style like? In a letter congratulating him on receiving the Order of Merit in 1949, T.S. Eliot wrote: "It is a fitting though belated tribute to the author of The Philosophy of Leibniz, and Principia and the other works on which I fed thirty-five years ago. And also to the author of the Reith Lectures - who is one of the few living authors who can write English prose." Aldous Huxley entitled his tribute to Russel1 "The Relevance of Style". Huxley praises in Russell's prose what Russell himself valued most in the art of writing - simplicity.

What a blessed relief it is to read what Bertrand Russell has to say about politics, or psychology, or the conduct of life, or Nobel Prize Acceptance Speech! No jargon, not a single neologism. Nothing but plain English. There is no hiding behind obscurities, no pretending that hie subject is understandable only by specialists and can be talked about only in a private language. Everything is perfectly clear and above-board. Of German scholars Bentley used to say that deeper and came up muddier than any others. Bertrand

Russell dives deep, but comes up every time as clean as a whistle.

Charles Sanger said that Russell's "admirable and lucid English style may be attributed to the fact that he did not undergo a classical education at a public school."

About Russeir's argumentative prose, the prose of his major metaphysical works, the layman can only say that it is at once simple and forceful, is free from jargon and is often enlivened with wit. But his literary prose, the prose of his books and essays on society, morals, politics and education and of his Autobiography, has certain other virtues which give them an important place in the history of English literature. The three most striking features of his style, present mostly in three different classes of his writings and in some measure in all of them, are wit, prophetic fire, and a tender lyricism. Russell's wit is much more than a flair for humorous expression, it is an aspect of his paradoxical nature, the idiom of a sceptic who must make fun of a world of make-believe. It marked his conversation and inevitably entered into his prose. T.S. Eliot's poem on Russel1, "Mr. Apollinax", depicts him at a party where "his laughter tinkled among the tea-cups" and "his dry passionate talk devoured the afternoon." Russell was fond of talking and pursued it as an art. Of his talk Beatrice Webb left a most interesting record of her impressions in the early years of this century.

There is a good deal of this wit in his essays, and sometimes it is to be found even in his philosophical works. An interesting example of wit in serious philosophical prose would be his remark on Aristotle in the History of Western Philosophy: "Aristotle's metaphysics, roughly speaking, may be described as Plato diluted by common sense." As CrawshayWilliams says, "implicit exaggeration was a factor in Russe11's wit". Russell acknowledged it when he told this friend of his that "it is almost impossible to be funny at the expense of an intelligent person's ideas without being also a little unfair to them." But was it intellectual irresponsibility? Russell would have said, no. For he could be no less unfair to himself and to metaphysics as a whole. In as serious a work as "The Philosophy of Logical Atomism", he says: "the point of philosophy is to start with something so simple as not to seem worth stating, and to end with something so paradoxical that no one will ever bel ieve it."

What I call the element of prophetic fire in Russell's prose makes its first appearance in his works during the first world war, and it is the quality that gives the writings of his last years their power. The first world war contributed a new dimension to his mind and his work. It gave him his role of a conscientious objector to the war, a role which cost him his position in Trinity College and put him in prison for six 
months. Russell described one vivid wartime experience to Eliot, who responded to it creatively in the we11-known passage in The Waste Land beginning with "Unreal City / Under the brown fog of a winter dawn". But the first literary result of Russell's new state of mind was Prineiples of Sacial Reconstruction (1916). A typical example of the style of this work is the passage on England and Germany "as almost mythical representatives of pride and envy", which occurs in chapter III. The moral fire produced still more powerful political prose in his last years, particularly in his writings on the nuclear bomb and the war in Vietnam.

of the lyrical element in his prose the obvious example is "A Free Man's Worship". I remember in the thirties students of English in Calcutta University would recite the last paragraph of this essay with the feeling with which they would recite a select page from the Areopagitica, Unto This Last or Sartor Resartus. In later years Russell would remark that the style of his essay was too rhetorical. But I would ask my readers to compare its last paragraph with the last paragraph of the last volume of the Autobiography, where the same style reappears.

Russell's relationship with the writers of his times is an interesting subject for study. It may even be a topic good enough for a doctoral thesis. Some work has already been done in the area and is included in English Literature and British Phizosophy, edited by S.P. Rosenbaum (1972). Russell had almost no active or significant connections with literary academics. But one such connection was with Lucy Martin Donnelly, who taught at Bryn Mawr. Russell once remarked to her: "I thank God I don't have to read Anglo-Saxon 7iterature"!

Russell did have friends among the most distinguished writers of his days. He knew and hated D.H. Lawrence. He summed up Lawrence's writing thus: "His descriptive powers are remarkable, but his ideas cannot be too soon forgotten." Russell made the acquaintance of Joseph Conrad in 1913. He was so fond of him that he named both his sons after him. There is an essay on Conrad in Portraits from Memory, and it may not be completely useless for the student of English Literature to have a look at it. Russell met Bernard Shaw for the first time at an International Socialist Congress in London in 1896 when he had already read and admired Shaw's Quinteseence of Ibsenism. His final judgment on Shaw is that "as an iconoclast he was admirable, but as an eikon rather less so." Russell met H.G. Wells for the first time at a small discussion society in 1902. They were friends notwithstanding We11s' approval of the first world war as a "war to end war", a phrase he invented. In Russe11's view "Wells' importance was primarily as a liberator of thought and imagination".

Russell's obiter dicta on the great writers of the past are significant if only as an expression of the literary tastes of an eminent philosopher. He seemed to agree with the view that "Homer, so far from being primitive, was an expurgator, a kind of eighteenth-century rationalizer of ancient myths, holding up an upper-class idea of urbane enlightenment." "Euripides was influenced by Protagoras and by the freethinking spirit of the time and his treatment of the myths is sceptical and subversive." "Aristophanes made fun of Socrates, sophists, and phi10sophers, but nevertheless belonged to their circle." "Dante, though as a poet he was a great innovator, was, as a thinker, somewhat behind the times:" "Carlyle is the onty author who knows the place of history amiong the Fine Arts." "What is valuable in Tolstoy is his power of right ethical judgments, and his perception of concrete facts; his theorizings are of course worth1ess. It is the greatest misfortune of the human race that he has so little power of reasoning." Russell particularly enjoyed historians like Gibbon, who wrote "with lively fancy, and not merely with cold desire to chronicle facts". There are books of history, he says, that one can read "in the same spirit in which one reads poetry or a good novel".

Obviously remarks such as these, the chapter on Byron in the History of Western Prizosophy, or even "Is Literature a Dead Art?", will not give Russell a place in the history of literary criticism. But is there anything in his writings to give him a place in aesthetics? It was a philosopher who laid the foundation of poetics even when he denounced poetry. Another philosopher defined tragedy with such insight that even a schoolboy cannot talk about it without mentioning that definition. In this century it was a philosopher who significantly defined comedy. And between Aristotle and Bergson philosophers have given their ideas on the essence of art and poetry. Russe11, however, did not write a book or even an essay on aesthetics as such.

We have discussed his observations on style and on history as literature. Although they do not represent an original point of view, they have significance as Russell's literary ideas. The oniy other literary question he introduced in his writings concerned the nature of tragedy. In a letter to Gilbert Murray in 1902 he agreed with Plato's view in the Republic "that tragic poets ought to make us feel virtue to be beautiful, and ought (on the whole) to avoid the praises of vice. His austerity in matters of Art pleases me, for it does not seen to be the easy condemnation from the Philistine." In the same year Russell wrote on tragedy in "A Free Man's Worship":

of all the arts, Tragedy is the proudest, the most triumphant; for it builds its shining citadel in the very centre of the enemy's country, on the very summit of his highest mountain; fromits impregnable watch. towers, his camps and arsenals, his colunns and forts, are all revealed; within its walls the free life continues, while the legions of Death and Pain and Despair, and a11 the servile captains of tyrant Fate, afford the burghers of that dauntless city new spectacles of beauty.... 
It is certainly not the style of arguing an aesthetic theory; it. is much rather in the manner of a choral ode on tragedy such as a Swinburne would compose. But it contains a significant conception of tragedy: that it is man's brave answer to his inevitable doom, his attempt at giving a meaningful and satisfying form to his suffering. More than a quarter of a century later Russell returns to the subject in The Conquest of Happiness. Comparing Ecclesiastes with J.W. Krutch's The Modern Temper, he says that while the former is "tragic" the latter is "pathetic":

the cosmic significance of an individual death is lost to us because we have become democratic, not only in outward forms, but in our inmost convictions. High tragedy in the present day, therefore, has to concern itself rather with the community than with the individual. I would give as an example of what I mean Ernst Toller's The MassMan. I do not maintain that this work is as good as the best that has been done in the best ages in the past, but I do maintain that it is justly comparable; it is noble, profound and actual, concerned with heroic action, and "purging the reader through pity and terror", as Aristotle said it should.

Russe11 introduces the Aristotelian doctrine of Katharsis but does not explain how far it explains the psychology of the tragic response to life as described in "A Free Man's Worship." We can only assume he be1 ieved that what Aristotle wanted to say through Katharsis was what constituted man's moral victory over suffering in tragedy. This gives fresh strength to the theory of Katharsis as an answer to Plato's charge that the tragic poets oniy nourish the passions and desires. It offers an aesthetic approach to the doctrine that matches Ingram Bywater's specifically pathological approach. The essence of Russell's view of tragedy is that it gives beauty to suffering and thereby makes it not only bearable but somehow enjoyable. In a 1907 letter to Murray, Russell admires his transiation of Euripides' Hippolytus. He says it is a "tragedy [which] fulfils perfectly ... the purpose of bringing out whatever is noble and beautiful in sorrow; and to those of us who are without a religion, this is the only consolation of which the spectacle of the world cannot deprive us." Russell wrote more in disconnected places on tragedy, and I think his unique view of it might well be pursued.

Russell is not well-known as a writer of fiction. In 1912, however, he did try his hand at short-story writing. The result was recently published as "The Perplexities of John Forstice" in The Collected Stories of Bertrand Russelt. It has undoubted autobiographical significance. The two original volumes of his short stories, satan in the Suburbs (1953) and Nightmares of Eminent Persons (1954), do not contain any piece which can be considered as one of the great short stories in the language. But they are significant as the work of an imaginative philosopher who occasionally valued fancy for expressing thoughts and feelings. Russell knew, as he confesses in the Autobiography, that editors and readers were "reluctant to accept me in the role of a writer of fiction." But why did he try his hand at something which he knew his readers did not expect? "My defence for writing stories is that I have often found fables the best way of making a point", he wrote. He believed that his fables making fun of the philosophy of "Common Usage" damaged its prestige.

Perhaps the most important question in a consideration of Russell's achievement is, did he produce a great book? Russell himself asked this question about modern writers.

The decay in the writing of great histories is only a part of the decay in the writing of great books. Men of science nowadays do not write books comparable to Newton's Frincipia or Darwin's Origin of Species. Poets no longer write epics. In the learned world, everything moves so fast that a massive book would be out of date before it could be published ... few men in any branch of learning feel that there is time for that leisurely survey from which great
books formerly sprang.

He made an exception of Toynbee's Study of History. But would he have made an exception of any of his own works? We cannot say. Philosophers will have their doubts if only because Russe 11 was always developing as a metaphysician, and not one work of his can be read as a final comprehensive statement of his philosophy, despite the magnificent attempt of Iluman knowledge. He knew this more than anyone, and therefore wrote My Philosophical Development as a kind of metaphysical autobiography. Even if Pxincipia Mathematica or Our Knowledge of the External world or any other work of comparable magnitude be recognized as a great book, it is so only for the specialists. I do not deny that all of Russell's major philosophical works may be philosophical classics. But the History of Westem Phizosophy is the only philosophical work of his that can also interest the lay reader, and it is certainly less than a classic in the sense of a great book.

His political and social prose has both charm and power, but perhaps no particular work in this class of his writings is quite a great book, in the sense of a classic in world 1iterature, though Principles of Social Reconstruction is great of its kind. His three-volume Autobiography could have been a great book: it has vivid and picturesque descriptions, it has a few passages of great Tyrical charm, it has wit and many interesting anecdotes. Yet it is not as great a work of autobiography as the Confessions of Rousseau, the Autobiography of Gibbon and of John Stuart Mill, or the Apologia pro Vita Sua of Cardinal Newman. What weakens Russe1l's Autobiography is its lack of form, its rich documentation through innumerable letters which, however, interrupt its movement. Russell was not careful in reducing his archival material to the minimum: the diary of his soul is cluttered up with too many documents. If the art of autobiography demands a selective recollection, Russe11 weakened his by remembering too much. Yet I am told that Russell refused to allow any cheap edition of the Autobiography minus the appendices. 
This inattention to form or an incapacity to master it is evident in almost all his works. (An exception can be made of the Problems of phizosophy and perhaps of some other early books.) Russell could turn out beautifur sentences and construct fine paragraphs, but he did not care to give a formal perfection to the whole work. Perhaps he did not believe in such perfection and depended on spontaneity. He rejected Pearsall Smith's advice to polish his writing, and he could not afford to polish when he wrote so much. And if he did not believe in revision of style and design he did not believe in distillation of thought either. A great book emerges out of years of reflection on what one must say and how it is to be said. Russell had great things to say and he had the eloquence to say it. But the eloquence of a great soul by itself does not make a great book. The architectonic quality of a work gives it its unity, and there is little depth without this. Russell depended almost entirely on the greatness of his thoughts and the expressiveness of his phrases. He was indifferent to the design of the whole.

I was afraid this impression of mine would be too uncomplimentary to such a great writer, yet I had no means of comparing notes with other literary critics because little has so far been written on him from a literary point of view. But I have discovered at least one supporter in Russe11's friend and biographer, Alan Wood, who says:

He was a stylist who wrote passages which deserve a place in any anthology of English prose; but his books tend to be collections of disconnected chapters, instead of adding up to a complete whole. This is, of course, a natural enough corollary to his analytical and piecemeal approach to any problem, and his rejection of monism.

I must however add this to Wood's remark, that to Russell this was the only approach and he thought his style was enough to express it. He was, in a sense, deliberately unliterary from the viewpoint of literary art. To him the one serious defect in Erasmus was, as he puts it in the History of Western Philosophy, that he "was incurably and unashamedly literary". Russell's avoidance of this defect is partly responsible, of course, for his great simplicity of style.

And yet Russell was a great writer, when we take into account all that he wrote. His seventy books, and innumerable articles and letters yet to be collected in books, constitute the epic of a great mind capable at once of acute thought and tender feeling, a mind that made the hopes and fears of his times his own and interpreted them for a world-wide posterity. No other English author, not even Milton who too was involved in public affairs, had such a wide range of thought and feeling and could bring his prose so close to to the business and bosom of his contemporaries. And in this sense Russell is the ideal man of letters for the world we are living in today. 